\title{
Aspects and Format Form of Interaction Teacher-Student during the Classroom
}

\author{
Prof. Asoc. Dr. Behxhet Gaxhiqi \\ Faculty of Education, \\ University of Gjakova "Fehmi Agani", \\ Prishtine, Kosovo
}

\begin{abstract}
The nature and specificity of this paper will focus on several dimensions of the fields of study. In the first dimension we will be focused on scientific arguments, interlinking with the findings of the research, but also by comparing them with the new findings. In the second dimension of this research we will analyze how to explain and argue how the learning method, the forms of work in groups, the role and impact of the new curriculum affect the academic achievement, at the level of the teachers but also at the level of the degree of understanding students learn and learn. Namely, the transition from classical teaching to the teacher-centered, center-going student. The topic of this paper is focused on providing sufficient theoretical and practical data from the pedagogical science literature of the time regarding the importance of teaching and interactive learning in learning. We will analyze our research work, compare the old methods and use of new contemporary methods, with particular emphasis on the model of differentiated teaching methods in the lower primary cycle. The study also argued the introduction of different terms of the teaching model in the technique and the model of the theory of teaching - learning and interactive learning in the lesson.
\end{abstract}

Keywords: Comparison, sketching, modeling, advancement, thematic, classical learning

\section{Introduction}

Understanding the necessity and the necessity of the level and advancement of the advancement of the teaching model in learning. Starting with many problems highlighted in the abstract of the paper, at the beginning of this paper we will concentrate on several dimensions and aspects for to explore, to highlight this thematic of work, which is vital to knowing and studying by the experts of this field and broader. The first part of the paper consists of four headings. Levine, M. (1987). In the first place, the study aims to reveal the analysis, the problems of teaching methods, their role and their impact on the school practice. A teacher to be successful should, besides professional preparation, management skills, student-dedicated work, parenting, and so on. It has to apply different models of teaching in order to motivate learners to learn and adapt to their interests and learning styles. Ashby, J. S., Kottman, T., et al. (1998. It should be noted with a high epithet one of the main works that has written about this 


\section{Journal of International Cooperation and Development \\ www.richtmann.org/journal \\ Vol 3, No 1, May 2020}

matter, is scientific and academic work Jashar Rexhepagic See also: Fundamental issues in international pedagogy published by the Kosovo Academy of Sciences and Arts in Pristina in 2008. (J.R. Agiq, 2008) This model and aspect of learning aims not only to facilitate schools in the development of learning processes by placing the learner at the center motivating it to learn in a variety of ways to meet the standards required by the school curriculum but also to 'used his / her knowledge and skills in the social environment and in the service of the community. Rosen, J. C-, \& Gross, J. (1987). Active learning processes require greater engagement of teachers and students, but they also need parents' support, and these innovations and practices suggested in this module initiate close relationships, collaboration between teachers-students and parents within the hours but also through forms of student interaction in the social environment where they live, in which they will use their knowledge and skills to support community needs, and will enrich their learning experiences and therefore and their knowledge and skills that can be of value throughout their lives. In pedagogical science literature, there are different classes and modalities of teaching, such as direct teaching, cross-curricular teaching, active teaching, interactive or interactive teaching etc. (S. Kuqi, A. Rraqi, 2013).

\section{Explaining the Teaching Model in Scientific-Pedagogical Literature}

Numerous ideas for the teaching model have proved at the same time that he is present at school as a process fully integrated into the education system. This implied the necessity of learning participation within teaching classes, educational activities, training, but also in other extracurricular activities. Concerning this point of view, there were conflicting ideas. The ongoing clashes that existed and in some cases encounter today are related to opposing views on the teaching-learning relationship. So not only in our school but also in European countries, studies have noted that for a very long time, the dominant in the school has been the teaching, which implies a teaching process that was ruled by the teacher. Vidovi, $V$. (1998). He developed where the many developments in the field of education, with the reforms carried out year after year in the entire education system, but also in specific areas of education, ranging from national strategies, curriculum frameworks, school curricula, textbooks, evaluation, management, teaching, etc., an enrichment and extension of the terminology of this field has been noted.( S. Dion, Nr.1, 1995).The curriculum, he possessed almost the necessary and indispensable time of the lesson. "In the vocabulary of pedagogy education "is defined as" a system of generalized knowledge and generalizations in the sciences on nature, society and human thought that are planned and programmed in educational institutions (schools, courses, etc.) to learn and educate the young generation and the masses of workmen, a scalable system through which knowledge, skills and skills are given, the result of the acquisition of the system of knowledge, skills and skills embedded in social practice. (O. Shefik, 1983.). Martin Seligman in 1970 


\section{Journal of International Cooperation and Development \\ www.richtmann.org/journal \\ Vol 3, No 1, May 2020}

proposed a continent of biological training for learning. The concept of biological preparation helps us to explain relationships in the field of emotions. (Seligman, M. E. P. (1970).

\subsection{Training in learning planning}

"Disruptive behavior" is defined as difficult or problematic behavior by a person or group. Usually refers to antisocial behavior rather than emotional behavioral disorder. According to Cambridge Dictionaries Online "break" means to stop something, especially a system, process, or event and not allow it to continue as usual. Disruptive behavior is defined in different ways by scholars. In the Hofstadter-Duke dissertation, disruptive behavior involves both mood and verbal disruption. Specifically, motion and verbal disorders collectively include the following behaviors: pencil collisions; drawing or writing on their own, on the desk or on any other surface not paper; making faces or gestures; unclassified speech such as learning involvement (egg, reading of problems, reading of loud problem solving steps), laughter, singing, crying and whistling. (A. Muharremi.2013).

\subsection{Model of teaching}

Teaching and learning are integrated into elementary school education, even above, with emphasis on one time, another, depending on the level and quality of the experience and the knowledge of the students. In didactic literature there are mainly two teaching models: Direct teaching with a focused focus on quick achievement of the knowledge of the facts, the rules, and the formation of skills for them, while the content of the subject is divided into small steps that are easily adopted. Pango, $Y$. (2004). The teaching process is supervised by the teacher. In direct teaching, the objective is to involve students in scrutiny and investigation, which helps shape and develop concepts in the form of patterns and abstracts. Patton, G.C., Selzer, R., Coffey, C., Carlin, J.B., \& Wolfe, R. (1999). The teacher, through questions to the students, leads them to discover and generalize, to evaluate their responses. In these learning situations the discussions are complementary actions to express thoughts in various forms. The teacher in these situations has the role of facilitator and moderator, who coordinates and organizes the learning process in interaction with the students. (O. smani, Sh., 1983.) Use of material-didactic base for new teaching material. Frost, R. O., Marten, P., Lahart, C. and Rosenblatt, R. (1990). This is another aspect when the teacher communicates with the students through the material-didactic background presented to the students to facilitate the successful understanding of the new teaching material by them. (I, Krasniqi, 2003). But this will be achieved when the teacher brings in the teaching the necessary tools that dictates the new teaching topic he will explain, and 


\section{Journal of International Cooperation and Development}

www.richtmann.org/journal

Vol 3, No 1, May 2020

when he knows how to move them for the purpose he has brought. For example, in the successful use of learning maps by teachers themselves or by students themselves (dumb maps). And when this is achieved, it means that the teacher has communicated successfully with the students with the didactic material base they used in the teaching aspect of the $\mathrm{x}$ or $\mathrm{y}$ topic. In this regard, I would say that not all teachers are successful. (Z.N, Didactic, P, 2005)

The group of teaching strategies for acquiring knowledge, which includes the acquisition of facts, rules, and implementing activities, is called direct teaching. While strategies for teaching teaching and solving the problem involving concepts, patterns and abstractions are called constructivist teaching, which has previously been called indirect teaching. Both types of learning combine in teaching with the use of strategies, methods and techniques different and enable students to choose a problem, think critically and work together. (Osmani, Sh., 1983). The interactive nature of learning. Both of these educational realities coincide with the ideas and concepts of the time in which they are developed, as well as with today's developments, more or less. This model learns in its way of development the more it masks and restricts it. In such cases, many teachers consider synonymous learning teaching. Davison, G. C. i Neale, J. M. (1999). The consequences that may arise in the many uses of this model are dangerous to many essential aspects of school learning, because according to this figure, this is a process that discards learning from learning. This outdated formula above is typical of "obsolete" traditional schools, which hinder the realization of direct interaction but of practical activities as very important components of learning. (I, Krasniqi,2003)

The above-mentioned linear relationship hampers maximum learning that is based on active interaction in the classroom. Another view and scheme brings interaction learning. The Teacher Skill This type of interactive learning is selected today by many teachers for learning their students for such reasons as follows: It has facilitated student understanding during the interaction process because it first gives a teacher the opportunity to work effectively with many students in the classroom and secondly promotes opportunities for inclusion and participation in learning activities of a larger number of students. (O. Shefik,2013). Indeed, this model enables real, two-way interaction and within each group enables the activation of a large number of students in learning. Fleming, J. S. \& Courtney, B. E. (1984). On the other hand, problems and concerns of this type are encountered during interaction as follows: - Teacher interaction is temporary (when he or she runs a group), - Equal activation of students is not guaranteed, - Type and mode the activation is not the same for all groups, so there is an opportunity to parcel the contents of the curriculum and an uncertain formation (each group learns only a part of the whole); Active teaching-teaching characterized by high levels of teacher explanation, demonstrations, interactions between teacher and student. Anchored Teaching-the type of learning that is based on the problem, a method that uses a complex and interesting situation as a learning axis. Kapor-Stanulovic, N. 


\section{Journal of International Cooperation and Development \\ www.richtmann.org/journal \\ Vol 3, No 1, May 2020}

(1999). Differentiated Teaching - a flexible teaching method that adapts learning content, process and product to student changes, displaying zeal, interest, and learning needs. Direct Teaching - Systematic Teaching for Mastery of Basic Skills, Facts and Information. Effective Teaching - Explanation of Lessons That Are Concise, Clear and Specific and Communicating an Expected Results. Presentations Work Better Than Questions. (B. Musai, 2014). Mutual Teaching - a method conceived to help students understand and think deeply about what they read. Introductory Teaching - Teachers present the teaching material in broader form to the more specific ones In contemporary didactics, which is necessary and the importance of the dynamic organization of learning, in collaboration with the psychosocial interaction between the primary social factors of learning, between the teacher-student-students, the activation of the student for self-study, self-development, self-authentication and self-affirmation, respectively gained knowledge, to develop skills and skills, and to form independently active skills during a particular part of the classroom, but also at home, represents the most objective learning objective and is known as the student's independent active learning .( Dykro, O.D.; Todorova, C.,1984)

\subsection{Interactive teaching}

Abrahamson notes that: in essence, interactive teaching is to give students something to do, taking what they have done, and then assimilating for themselves, so that it can be decided what will be better to do it afterwards. Abrahamson further lists the three reasons why teachers should choose interactive teaching. First, this is an attempt to see what actually exists in the students' brains. This is the "summary" aspect. It's the easiest aspect to understand and this is best described in literature. But it is far from being the only prospect. (G. Behxhet,2005). The second reason is formative, where the teacher intends through the assigned task to guide the mental processing of students along a proper path to "conceptual boon". The goal is, as students think through the necessary issues in overcoming the road, the resulting mental building that has developed in the student's head will have those features that the teacher is trying to teach the students. As Socrates has revealed, a good question can achieve this result better than simply giving the answer. The third reason can be called motivating. A motivational factor provided by the interactive teacher is the demand for a response to a lively task in the classroom. (M, Xheladin,2002).

\subsection{Characteristics of pedagogical interaction in schools}

Pedagogical interaction: The interdependence between student and teacher activities. Constructivist and social-constructivist theories with typical representatives Piazhen and Vigotski are more than ever finding support in written curriculum documents, but 


\section{Journal of International Cooperation and Development}

www.richtmann.org/journal

Vol 3, No 1, May 2020

especially in the curriculum implemented in school's Western countries. Fairburn, C. G. (1997). The views and practices suggested by the cited theories are deeply based on a spellbound interaction, recommending it in the field of education through active pedagogical interaction. It is this interaction that, according to social-constructivists, serves as a guarantee of success in the teaching process, but also that the diverse forms of learning provide desirable achievements of children-pupils outcomes. (Woolfolk Anita ,2011) The qualitative development of teaching and learning processes in European schools began when interaction processes were seen as an effective form of communication in classrooms. (M Bardhyl, 2014) (Researchers, researchers and authors of this field began to react and it turned out necessary to organize learning through new forms of communication in the classroom, which brought different roles of teachers and learners, brought new ways to broadcast and receiving teaching messages between the two main teacher-student partners. Herrin, M., \& Matsumoto, N. (2007). In general, pedagogical forms related to pedagogy within a child or the reduction of its learning processes now needed a school pathology and especially around it learning within the classroom, but also in the school's social environment. The teaching-learning relationship, already treated in a different spirit, is the first sign that makes us turn to the nature of the learning process in the school, which is now considered a type of interaction. (B. Riza,2011). This means that learning is understood in a much wider sense and includes all learning patterns, conditions, circumstances, fact-finding, modeling, but also complex aspects of learning such as: learning from research or discovering, experimenting, solving problems independently, creating individual knowledge, building social knowledge, formatting and system of attitudes, beliefs and values etc.)

The second, important feature of pedagogical interaction is its non-asymmetric nature closely related to learning as a fundamental function of it Hewitt, P. L., Flett, G. L. and Ediger, E. (1995. Asymmetric nature can be observed in many different ways: in the interaction between an adult and a small one, the interaction between a person with higher development and another with lower development or the development of many skills at once or more simply an interaction between one who has more knowledge about academic disciplines and the other who has the ability to learn quickly or different combinations of these symmetries, where a great and common challenge to school practice is the situation in which students with a low mental or physical development demonstrate more knowledge in specific disciplines. (H, Koliqi, 1987). The third feature, special of the pedagogical interaction is that the whole interaction is organized around a lot of knowledge, many objects of knowledge. Frost, R. O., Marten, P., Lahart, C. and Rosenblatt, $R$. (1990 Pedagogical interaction is not just an interpersonal relationship, a mutual, reciprocal relationship, a relationship between individuals, but the pedagogical interaction has as its integral part many knowledge and knowledge with all the characteristics of their nature. Fleming, J. S. \& Courtney, B. E. (1984). To build a knowledgeable corpus of knowledge, it should be possible to obtain as much knowledge 


\section{Journal of International Cooperation and Development \\ www.richtmann.org/journal \\ Vol 3, No 1, May 2020}

as possible, as well as of all kinds of knowledge, such as: different conceptual knowledge in different fields, practical knowledge relating to skills and habits, procedural knowledge that instruct the learner to recognize systems of rules, procedures, techniques and delivering answers during learning. Ibolya, G. (1999). These views have been applied in the current educational policy documents in our country dealing with with the content of the Curriculum Framework, with elements of the methodology of subject programs and or in fine detail in the instruction manual for teachers for different subjects and subjects.(Gjokutaj, M.; Hoti, I., Kadriu, D., 2016).After the 90s of the last century a valuable contribution in the field of good interactive practices, especially in the field of methodologies, has provided the implementation of many national education projects, which initiated and enabled concrete applications in the learning realities of the interaction classes pedagogically, mainly through the use of effective, interactive and active methods, techniques and strategies that have essentially learning, but especially its stimulation. Active interaction in classrooms is already highly embraced by teachers, students and parents, but also by school leaders and inspectors. (Gjokutaj, M.; Hoti, I., Kadriu, D., 1954).

\subsection{Interactional Types of Teaching and Learning Processes}

Given this learning mode. Different authorities present their concept of interactive teaching. They point out that when talking about interactive teaching, we need to understand teaching as a dynamic, flexible, open-minded interaction process between teachers and students, but also among students themselves, where everyone has the right to make decisions and choose the roles they fit into. Brownell, K. D.\& Fairburn, C. $G$. (1995). Interactive teaching requires new interactive roles, both inside and outside the school environment. Also, interactive teaching requires the use of new technologies in the right quality and ambitious educational goals. For this, the teacher has to look at himself as a student who learns for himself and for others, for his pupil. (Spiro Dion Revista pedagogies Nr.1, 1995).

Teacher I. Carter notes that there are several different ways to categorize classroom interaction, but all types of interaction are important to engaging learning and creating well-educated young people inside and outside the classroom. He distinguishes these types of interaction: student-teacher interaction, student-student interaction, interaction of a small group, and interaction of a class.

Tanner and others have the stance that interaction in teaching with the whole class in a continuation of the degree of teacher control / student, the nature of interaction and the character of the skeleton (construct) is ensured through dialogue. (Carneiro, $R$. (2000). Education, 2000). 


\section{Journal of International Cooperation and Development \\ www.richtmann.org/journal \\ Vol 3, No 1, May 2020}

\section{Conclusion}

In traditional teaching the curriculum is defined and developed by external experts. Making decisions is of an authoritarian-hierarchical character. Ambrosi - Randic, N. (2004). Teaching content is designed to support traditional expectations related to social behavior and academic achievement. Culture and other individual differences are ignored and children are expected to adapt to the dominant culture. Activities are based on book or workbook. Emphasis is on mastering the basic skills. The teacher alongside the book is the only source of information. Teachers present their information through lectures, workbooks and worksheets. (Islamaj, Sh,2004).

In interactive teaching, teacher-student-parent interaction in program content is visible and necessary. Teaching content is integrated and children collaborate. Teaching content depends on children's desires and interests. Decisions are taken jointly. (Grillo, K., 2003.The curriculum is designed to fit the individual potentials of children and create positive learning relationships. The curriculum respects variations and the multicultural world, in order to prepare students better for the future. Activities are based on various sources of information. The emphasis is on meaningful concepts. (Z, Nijazi,2005).

\section{References}

Ambrosi - Randic, N. (2004). Razvoj poremecaja hranjenja. Jastrebrovo: Naklada Sklap.

Ashby, J. S., Kottman, T., et al. (1998). Perfectionism and eating disorders reconsidered. Journal of Mental Health Counseling, Vol. 20 Issue 3, p261, 11p.

Brownell, K. D.\& Fairburn, C. G. (1995). Eating disorders and obesity: A comprehensive handbook. New Jork: The Guilford Press.

Coopersmith, S. (1967). The Antecedentes of Self-esteem. San Francisco: W. H. Freeman and Company.

Davison, G. C. i Neale, J. M. (1999). Psikologjia abnormalnog doživljavanja i ponašanja. Jastrebarsko: Naklada Slap.

Edlund, B., Halvarsson, K., Gebre-Mehdin, M. \& Sjödén, P-O. (1999).Psychological correlates of dieting in Swedish adolescents: A cross-sectional study. European Eating Disorders Review, 7, 47-61

Fairburn, C. G. (1997). Eating Disorders. In C. G. Fairburn and D. M. Clark (Eds.). Science and practice of Cognitive Behaviour Therapy (pp. 209 - 241). Oxford: Oxford University Press.

Fleming, J. S. \& Courtney, B. E. (1984). The dimensionality of self-esteem: II. Hierarchical facet model for revised measurement scales. Journal of Personality and Social Psychology, 46, 404 $-421$.

Frost, R. O., Marten, P., Lahart, C. and Rosenblate, R. (1990). The Dimension of Perfectionism. Cognitive Therapy and Research, Vol.14, No.5, pp. $449-468$.

Gustafson-Larson, A.M \& Terry, R.D. (1992). Weight-related behaviors and concerns of fourthgrade children. Journal of the American Dietetic Association, 92, 818-822 


\section{Journal of International Cooperation and Development}

www.richtmann.org/journal

Vol 3, No 1, May 2020

Herrin, M.,\& Matsumoto, N. (2007). The parent's guide to eating disorders. Carlbad-California: Gurze Books.

Hewitt, P. L., Flett, G. L. and Ediger, E. (1995). Perfectionism Traits and Perfectionistic SelfPresentation in Eating Disorder Attitudes, Characteristics, and Symptoms. Internacional Journal of Eating Disorders, Vol.18, No.4, 317-326.

Levine, M. (1987). Student eating disorders. Washington D.C.: National Education Association of the United States.

Pango, Y. (2004). Psikoterapi. Tirana: University Book Publishing House.

Patton, G.C., Selzer, R., Coffey, C., Carlin, J.B., \& Wolfe, R. (1999). Onset of adolescent eating disorders: population based cohort study over 3 years. British Medical Journal, 318, 765768.

Ibolya, G. (1999). Bezbedno dete u prevladanju ratnih trauma. Novi Sad: Solaris.

Kapor - Stanulovic, N. (1999). Kako pomoci deci u krizi. Beograd.

Kapor-Stanulovic, N. (1999). Organizacija psihosocialne pomoci. Beograd

Musai -B. (2014). Teaching methodology, Tirana

Muharremi-A.(2014). Learning management.

W- Anita,(2011). Educational Psychology, Tirana

Shimlesha -P.(1985) Pedagogjia, Prishtinë.

Zylfiu, N.(2006) Didaktika, Prishtinë.

Murati, Xh. (2002) . Didactics (Teaching Methodology), Tetovo

Mustafa, A. (2002.) .Didactics of the Albanin language and literary reading, Skopje.

Pedagogjia II, e. P. Shimlesha, Prishtinë, 1977

Pedagoška enciklopedia. (1989) I dhe II, Beograd, Zagreb.

Hajrulla-K. (1997), History of Word Pedagogy II, UP, Prishtina 